Relations industrielles

Industrial Relations

\title{
The Superior Labour Council
}

Volume 7, numéro 1-2, décembre 1951, mars 1952

URI : https://id.erudit.org/iderudit/1023121ar

DOI : https://doi.org/10.7202/1023121ar

Aller au sommaire du numéro

Éditeur(s)

Département des relations industrielles de l’Université Laval

\section{ISSN}

0034-379X (imprimé)

1703-8138 (numérique)

Découvrir la revue

Citer ce document

(1951). The Superior Labour Council. Relations industrielles / Industrial Relations, 7(1-2), 129-129. https://doi.org/10.7202/1023121ar

Tous droits réservés @ Département des relations industrielles de l’Université Laval, 1952
Ce document est protégé par la loi sur le droit d'auteur. L’utilisation des services d'Érudit (y compris la reproduction) est assujettie à sa politique d'utilisation que vous pouvez consulter en ligne.

https://apropos.erudit.org/fr/usagers/politique-dutilisation/ 


\section{INFORMATION}

\section{THE SUPERIOR LABOUR COUNCIL}

The Superior Council of Labour of the Province of Quebec is composed of twenty-four members, appointed by the Lieutenant-Governor in Council, upon the recommendation of the Minister of Labour.

Those persons who have been recently named members of the Council, as representatives of labour and capital, have been recommended to these positions by four labour organizations and six employers' associations. The list of members of the 4 th term of the Council now reads as follows:

\section{Group A - Labour representatives}

Recommended by the C.C.C.L. :

Mr. Gerard Picard and Mr. Jean Marchand. Recommended by the Quebec Federation of Labour :

Mr. Roger Provost and Mr. Roger D. Labrie.

Recommended by the Canadian Congress of Labour :

Mr. Jacques Chaloult and Mr. Philippe Vaillancourt.

Recommended by the Quebec Joint Legislative Committee of the Railway Transportation Brotherhood:

Mr. Jean Paul St. Pierre and Mr. A. Vincent.

\section{Group B - Capital representatives}

Recommended by the Canadian Manufacturers Association :

Mr. H. McD. Sparks, Mr. W. Mortimer Baker and Mr. C. N. Moisan.

Recommended by the Association des Constructeurs de Quebec Inc.:

Mr. Abel Ratte.

Recommended by the Retail Merchants Association of Canada Inc. (Quebec Division)

Mr. J. Arthur Juneau.

Recommended by the Canadian Pulp and Paper Association :

Mr. Jack R. Latter.
Recommended by the Professional Association of Industrialists :

Mr. Wilfrid Girouard.

Recommended by the Sherbrooke Board of Trade :

Mr. J. A. Archambault.

\section{Group C - Economists-Sociologists}

Mr. Leonce Girard.

Mr. J. B. Fontaine.

Mr. H. D. Woods.

Mr. R. J. Clark.

Mr. Paul LeBel.

Mr. Paul Henri Guimont.

Mr. Henri Ferron.

Mr. Jean Delage.

\section{Group D - Associate members}

Ministry of Labour :

Mr. Gerard Tremblay, Mr. Donat Quimper and Mr. Arthur Foster.

Department of Municipal Affairs :

Mr. Jean Louis Doucet.

Department of Trade and Commerce :

Mr. Louis Coderre and Mr. Fortunat Fortier. 